\title{
IMPROVING THE CAPABILITY OF FISH PROCESSING INNOVATION THROUGH INNOVATION SYSTEM STRENGTHENING
}

\section{PENINGKATAN KAPABILITAS INOVASI USAHA PENGOLAHAN IKAN MELALUI PENGUATAN SISTEM INOVASI}

\author{
Shanti Kirana Anggraeni ${ }^{1{ }^{*}}$, M. Syamsul Maarif ${ }^{2)}$, Sukardi $^{\text {3) }}$, Sapta Raharja ${ }^{3)}$ \\ ${ }^{1)}$ Industrial Engineering Department, Faculty of Engineering, Sultan Ageng Tirtayasa University, Cilegon, Banten, Indonesia \\ E-mail of the corresponding author: s.kirana@untirta.ac.id \\ ${ }^{2)}$ Business School, Bogor Agricultural University, Indonesia \\ ${ }^{3}$ Department of Agroindustrial Technology, Faculty of Agricultural Engineering and Technology, Bogor Agricultural University
}

Makalah: Diterima 13 Agustus 2018; Diperbaiki 21 November 2018; Disetujui 18 Desember 2018

\begin{abstract}
ABSTRAK
Industri pengolahan hasil perikanan di Provinsi Banten memiliki potensi yang baik tetapi memiliki kapabilitas inovasi yang rendah. Penelitian ini bertujuan untuk menghasilkan model konseptual bagi peningkatan kapabilitas inovasi Usaha Kecil Menengah (UKM) olahan ikan di Provinsi Banten. Penelitian ini menggunakan pendekatan penelitian tindakan berdasarkan Soft System Methodology (SSM). Hasil penelitian menunjukkan bahwa rendahnya kapabilitas inovasi dari usaha kecil menengah pengolahan ikan di Provinsi Banten disebabkan oleh rendahnya kerjasama dan interaksi di antara pelaku inovasi. Yang direkomendasikan sebagai usaha perbaikan adalah penguatan sistem inovasi, dengan cara meningkatkan kolaborasi inovasi di antara empat aktor inovasi, yaitu UKM, pemerintah daerah, universitas dan lembaga penelitian lainnya, serta masyarakat, disebut juga Quadruple Helix Innovation, melalui program (1) kurikulum berbasis technopreneurship dan inovasi, (2) inkubasi bisnis (3) standarisasi dan sertifikasi produk perikanan, (4) diseminasi hasil penelitian, dan (5) Science Park / Technopark berbasis pengolahan ikan.
\end{abstract}

Kata kunci: pengolahan ikan, sistem inovasi, Quadruple Helix, Soft System Methodology

\section{ABSTRACT}

Fishery processing industry in Banten Province has good potential but has low innovation capability. This study aims to produce a conceptual model for improving the innovation capabilities of Small and Medium Enterprises (SMEs) processed fish products in Banten Province. This research used the action research approach based on Soft System Methodology (SSM). The results showed that the low innovation capability of smallmedium fish processing businesses in Banten Province was caused by low cooperation and interaction among innovators. What is recommended as an improvement effort is strengthening the innovation system, by increasing innovation collaboration among the four innovation actors, namely SMEs, local governments, universities and other research institutions, as well as the community, also called Quadruple Helix Innovation, through programs (1) technopreneurship-based curriculum and innovation, (2) business incubation (3) standardization and certification of fishery products, (4) dissemination of research results, and (5) Science Park / Technopark based on fish processing.

Keywords: fish processing, innovation system, Quadruple Helix, Soft System Methodology

\section{INTRODUCTION}

Fisheries product processing business activities in Banten Province in general are still dominated by small and medium scale businesses (UKM) with all their limitations. From the results of Nur (2012); Nurhidayani (2012); Puspitasari (2014); and Hasibuan (2015) research, it is known that processed fish products in Banten Province still rely on the local market, safety and hygiene have not been fulfilled, low product storage, packaging design and the label has not been standard, lack of capital, and small business scale so that efficiency is also low. The quality of products, technology, packaging and markets is growing. This shows that SME fish processing in Banten Province does not yet have sufficient capability or capability to strive for product quality, process, marketing, and service improvements, or what is called innovation capability. According to Mulyana and Sutapa (2014), the capability of innovation is the ability to apply creativity in order to solve problems and opportunities to improve performance through technological innovation, product innovation, market innovation, and service innovation. While innovation is a factor that enables change to lead to improvements in people's lives.

To improve the capability of innovation, a systemic perspective or approach is needed as a tool to improve innovation policies at various levels. For this reason, an innovation system approach will be used that includes all parties to work together and be responsible, both from universities, government, 
businessmen, and the community (Quadruple Helix). The innovation system is a unity of a set of actors, institutions, networks, relationships, interactions, and productive processes that influence the direction of development and the speed of innovation and its diffusion (Lundvall, 1992; Nelson, 1993, Metcalfe, 1995). In other words, the innovation system is a system of technology flows and information between institutional developers and technology users, supported by other related institutions.

This study aims to create a conceptual model for improving the innovation capability of fish processing SMEs in Banten Province based on the innovation system and Quadruple Helix, namely a collaboration model of innovation or an innovation environment where the academic world, government, industry, and society work together to produce innovation. In this study focused on SME milkfish satay processing, which from the results of research by Hasibuan (2015) and Anggraeni et al. (2018) satay bandeng was chosen as the superior product of fish processing UKM in Banten Province.

\section{METHODOLOGY}

This research used the action research approach based on Soft System Methodology (SSM) which viewed the field fact (real world) as a system consisting of the interconnected and interrelated subsystem. Checkland (1981) stated, SSM is a tool for observing messy, complex, mysterious and holons field facts, and then analyzing, and drawing conclusions about what was observed. Soft system methodology (SSM) is an appropriate approach for studying complicated systems of human activities (Zarei et al., 2014). SSM also places emphasis on people's perceptions of reality and works with ideas about problem situations where various players may feel various problematic aspects.

SSM formalizes an inquiry system that is expressed to enable learning and to understand complex situations to allow management to initiate actions that aim. (Sadri and Sadri, 2014). The SSM approach clearly requires that different people and groups have different worldviews, which involves them as a human activity system which consists of a series of interrelated activities in a logical structure that makes the whole directed (Tajino et al., 2005).

There are four types of activities in SSM, which form the learning cycle, which is (1) Understanding the problematic situation, (2) Select the specified activity model, (3) Find more information about the situation, and (4) Defines actions, which makes the situation better (Delbridge, 2008). SSM makes a clear distinction between a messy and complicated 'real world' part which is the subject of several forms of inquiry, and a conceptual reference model, which is used to compile the inquiry (Wilson dan Haperen, 2009).
Some studies using Soft System Methodology (SSM) include Liu (2012) who uses SSM to identify and analyze stakeholders from an organization at various levels (Liu, 2012), Fadhil et al. (2018) who developed a quality management system strategy using SSM, Sgourou et al. (2012) use SSM to evaluate occupational health and safety performance (K3) and support decision making for safety improvement programs. Soetara et al. (2018) use SSM to design conceptual models from Lean Mannufacturing, Zarei et al. (2014) use SSM to describe the marketing and advertising industry in Iran, Sadri and Sadri (2014) use SSM to understand the process of implementing social responsibility from companies. The study procedure used SSM by using the developed stages by Checkland (1981). SSM stage consisted of seven stages as presented in Figure 1.

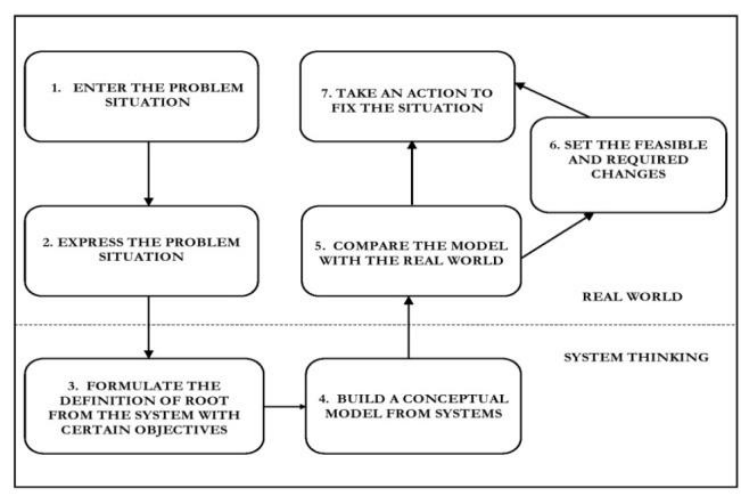

Figure 1. Stages of Soft System Methodology (Checkland, 1981)

(1) Enter the problem situation. The first stage, in the real world, is to accept, investigate, and determine the situation in one way or another. Here, we do not define the problem but absorb as much information as possible about the problem. The data collected will provide an informal picture of the problem (Checkland \& Scholes, 1990), while, at a later stage, it will provide a richer picture, which is a flexible graphic technique that represents a situation, problem or concept.

(2) Expressing the problem situation. The obtained material in the first stage then used to build a rich picture (depiction of the real world map) or also called the representation of the current state. This picture illustrated the activity process of each institution and the actors involved in the situation which indicated elements structure, communication flow and individual interpretation environment (Sonatha and Prayama, 2011; Eriyatno and Larasati, 2013). In the rich picture depiction, there is no established technique or distinctive form to present a rich picture, the image is usually displayed as a mind map (Nagi et al., 2012). 
(3) Formulate the definition of root from the system with certain objectives. The third stage of this methodology describes a system that is suitable and interrelated. This system has been introduced as a central definition (Checkland and Scholes, 1990). The methodology moves into the field of systemic thinking, applying extraordinary system concepts to describe how the system is At this stage, the basic definition is compiled by the assembly. This section was to define the root definition, which was a short sentence that stated "a system performs P by means of Q to reach R". Root definition was then poured in the CATWOE mnemonic as presented in Table 1 .

CATWOE shows a mechanism or checklist to check the main definitions and ensure that the terms chosen are as clear as possible and that they represent the best choice for the meaning they take (Nagi et al., 2012). The root definition is usually considered as a limited explanation of the system what to do, who will carry it out and who is responsible for doing it (Por, 2008).

(4) Build a conceptual model from systems. Based on the root definition that has been developed for each element that is defined, then the conceptual model is needed to achieve the ideal goal. This conceptual model was an adaptive process because there was feedback between the process of modeling with the results of the expression of the problem situation. All elements contained in CATWOE were included in the conceptual model.

(5) Compare the model with the real world. Stage 5 is a stage that refers back to the real world. At this stage, the conceptual model, which was made in stage 4 , will be compared to the real world stated in stage 2 (Por, 2008). Conceptual models were compared to the real world to highlight the possible changes in the real world. Each involved parties provided perception and assessment of the modeled activity, to determine a choice of models that would be mutually agreed upon. This model would be a recommendation for change.

(6) Set the feasible and required changes. Stage 6 is used to identify the various possible changes in terms of desirability and possibility (Por, 2008). The purpose of this stage was to identify and find the desired changes systemically and culturally appropriate. The changes could occur in terms of structure, procedures, or people's attitudes.

(7) Take an action to fix the situation. At this stage, there would be a change recommendation to be implemented. It would show the right system to make changes that its activity could be a "real world". Stage 7 is the last stage where the most beneficial and possible changes are implemented (Por, 2008). Here will be given recommendations for change.

In this study, data collection at each stage of the Soft System Methodology was obtained through discussion and interviews with 10 experts, who were representatives of universities ( 2 people), other research institutions ( 2 people), fish processing UKM ( 2 people), local government ( 2 people), as well as media and consumer associations ( 2 people).

Table 1. The element of CATWOE and their definition (Mingers, Liu \& Meng, 2009)

\begin{tabular}{cl}
$\begin{array}{c}\text { CATWOE } \\
\text { Elements }\end{array}$ & \multicolumn{1}{c}{ Description } \\
\hline $\mathrm{C}$ & Customer: Direct beneficiary or victim of the system's output \\
$\mathrm{A}$ & Actors who carry out the activities of the system \\
$\mathrm{T}$ & Transformation that produces the output as a transformed version of the input \\
$\mathrm{W}$ & Weltanschauung/worldview that makes the activities of the system meaningful \\
$\mathrm{O}$ & Owner of the system a wider system that can create or destroy it \\
$\mathrm{E}$ & Environment of the system, especially constraints \\
\hline
\end{tabular}

\section{RESULT AND DISCUSSION}

\section{Enter The Problem Situation}

Based on the results of interviews with innovation actors, that was SMEs, local government, universities and research institutes, as well as the community, obtained a variety of information that was a situation of unstructured problems. Here are the results of interviews and discussions with the innovation actors SMEs of satay milkfish processing in Banten Province.

1. Milkfish satay products had a durability that was not too long. The problem of product innovation of these fish processed SME also became a finding in the research of Haryati and Munandar (2012); Puspitasari (2014); Wibowo et al. (2014), and Hasibuan (2015).

2. Limited working capital. SMEs were difficult to apply for loans to banks if without collateral. This was in accordance with the research's result of Nurhidayani (2012) and Hasibuan (2015).

3. There is no standardization on products or packaging. In the packaging, there is no complete information about the product, for example, information on nutritional value, shelf life, subsequent processing methods. Most SMEs also have not included a halal certification on their product packaging. There is no assistance for SMEs to obtain 
certification. The problem of standardization and certification of SME products is also a finding of Hasibuan (2015).

4 Labor in fish processing businesses generally did not have special skills and only educated from junior or high school. The owner of the company besides acting as the owner was also responsible for marketing and production. The quality problem of human resources in this fish processing SME was also in accordance with Nurhidayani (2012) and Hasibuan (2015).

5. The absence of standardization on products and packaging. In the packaging, there was no complete information about the product, such as information on nutritional value, shelf life, and the next way of processing. Most of SMEs also did not include a halal certification on the packaging of its products. The problem of standardization and certification of SME products was also found by Hasibuan (2015).

6. Coaching overlaps often occur from agencies within the scope of the regional government, as well as with universities. The assistance of tools, facilities, and other production facilities from the local government, large companies, and universities is not followed by mentoring efforts.

7. Research has been carried out by many universities, but there are limited funds to follow up on laboratory-scale research that has been carried out. Research is generally carried out based on the latest topics, not based on the needs of consumers or SMEs. This is also a finding in Agustina's (2011) study. Dissemination of research results is only carried out among academics, not end users, or policymakers. In addition, there are still many research results or works that have not been registered to obtain IPR (Intellectual Property Rights) and Patent protection.

8. The community only acts like a user, there is no feedback to producers or other parties to provide input for innovation.

\section{Expressing The Problem Situation}

The next step was to organize the ideas through problematic situations systematically based on the obtained information. Furthermore, the unstructured problem situation was broken down into structured problems through the rich picture presented in Figure 2.

\section{Formulate the definition of root from the system with certain objectives}

In SSM, the first and second phases were part of the real world stage. In this real-world stage, the occurred problem and found in the location of research was disclosed. RDs (Root definitions) were the structured descriptions of a human activity system that relevant to the problem situation of concern in action-based SSM research. Checkland and Poulter (2006) suggested using the PQR general formula in preparing an RDs. The PQR formula did the $\mathrm{P}$ with $\mathrm{Q}$ to realize the $\mathrm{R}$.

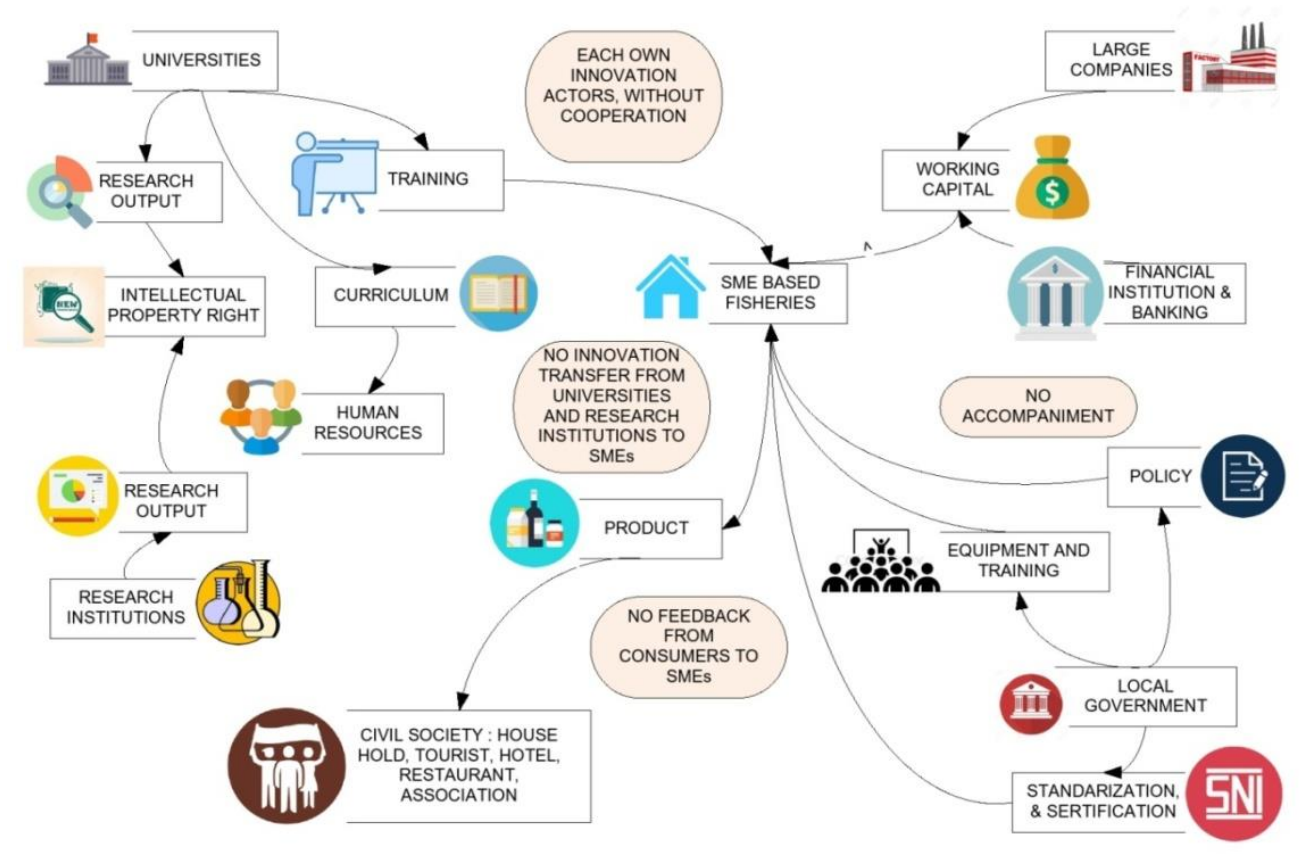

Figure 2. Rich Picture Description of Milkfish Satay SME problems 
Table 2. CATWOE for Root Definition Innovation Capabilities

\begin{tabular}{|c|c|}
\hline Description & Definiton Result \\
\hline $\begin{array}{l}\text { Customer: } \\
\text { people that influenced/ } \\
\text { being influenced by a } \\
\text { system }\end{array}$ & $\begin{array}{l}\text { Small and medium scale business actors, Universities/Research Institutions, } \\
\text { Local Governments, Communities, and Associations }\end{array}$ \\
\hline $\begin{array}{l}\text { Actor: } \\
\text { people who play a role in } \\
\text { system activity }\end{array}$ & $\begin{array}{l}\text { - Small and medium Business Actor: people who innovate or accept the } \\
\text { transfer of innovation from other innovation actors, in the process of } \\
\text { production and marketing of their products } \\
\text { - University/Research Institution: acted as a provider of innovation and } \\
\text { technology, human resources, as well as business and technology incubator } \\
\text { - Local Government: acted as a provider of regulation and policy as well as a } \\
\text { mediator between innovation actors } \\
\text { - Civil society: besides being a product consumer, it also provides feedback } \\
\text { for product innovation and processes for SMEs }\end{array}$ \\
\hline $\begin{array}{l}\text { Transforn } \\
\text { process anc }\end{array}$ & $\begin{array}{l}\text { Increased interaction and collaboration with innovation actors: } \\
\text { from low to high } \\
\text { Increased technology-based innovation in SMEs: } \\
\text { from low to high }\end{array}$ \\
\hline $\begin{array}{l}\text { Worldview: } \\
\text { the impact of system } \\
\text { implementation }\end{array}$ & $\begin{array}{l}\text { Increasement of SMEs' innovation capability was very important to be } \\
\text { conducted in order to achieve a stronger innovation system toward a better } \\
\text { product quality and could continue to compete with other similar products } \\
\text { from other regions }\end{array}$ \\
\hline $\begin{array}{l}\text { Owners: } \\
\text { related parties }\end{array}$ & Actor of milkfish satay small and medium enterprises in Banten Province \\
\hline $\begin{array}{l}\text { Environment : } \\
\text { the environmental } \\
\text { constraints surrounding the } \\
\text { system and its implications }\end{array}$ & $\begin{array}{l}\text { - There is no means or collaboration that brings together all innovation actors } \\
\text { - There has been no marketing cooperation policy in modern retailers } \\
\text { - Limitations of innovation infrastructure }\end{array}$ \\
\hline
\end{tabular}

\section{Root definition :}

Systems that conduc enhancement SMEs (P) of fish processing, innovative capabilities through enhancement of interaction and cooperation between SMEs, local governments, universities and research institutions, and communities (Q) to strengthen the SME innovation systems in order to achieve competitive SMEs (R).

\section{Build a Conceptual Model From Systems}

System activities on the conceptual model of enhancing the capabilities of SME innovation are as follows:

\section{Technopreneurship and Innovation Based} Curriculum

In general, technopreneur reflects an entrepreneur who combines existing production factors to produce goods and services in an innovative and technological manner and overrides existing risks (Lumpkin and Dess, 2001). In other words, technopreneurship is closely related to technology and is considered as the driving value of national competitive advantage. Technopreneurs play an important role in the economy by carrying a heavier burden because they use technology to create and improve products, services, and production processes. (Jusoh, 2006)

Basically, a technopreneur has a mindset and character from an entrepreneur. Entrepreneurship is the ability or skill to use and combine all resources, such as labor, capital, technology, and others to maximize profits. However, technopreneurship emphasizes more on the basis of technology implementation in running its business, especially the development of new products and innovations. So technopreneur is a modern entrepreneur based on technology, where innovation and creativity dominate to produce superior products in the era of a knowledge-based economy (Kosasih et al., 2016). Technology is not only about the hi-tech or technical problem but can also refer to the application of human useful knowledge that can benefit society (Ibrahim et al., 2015).

\section{Intensification of Business Incubation Program and Fish Processing Technology}

Business incubators are institutions that help entrepreneurs by facilitating the implementation of innovations in related industries so that they can survive in a real business environment (Jamaran, 2009; Agustina, 2011). Incubators can also be used as a bridge of interaction between sources of innovation (community research institutions) and users (especially entrepreneurs) in the development of further innovation. Business incubators are one model in fostering technology-based entrepreneurs. 


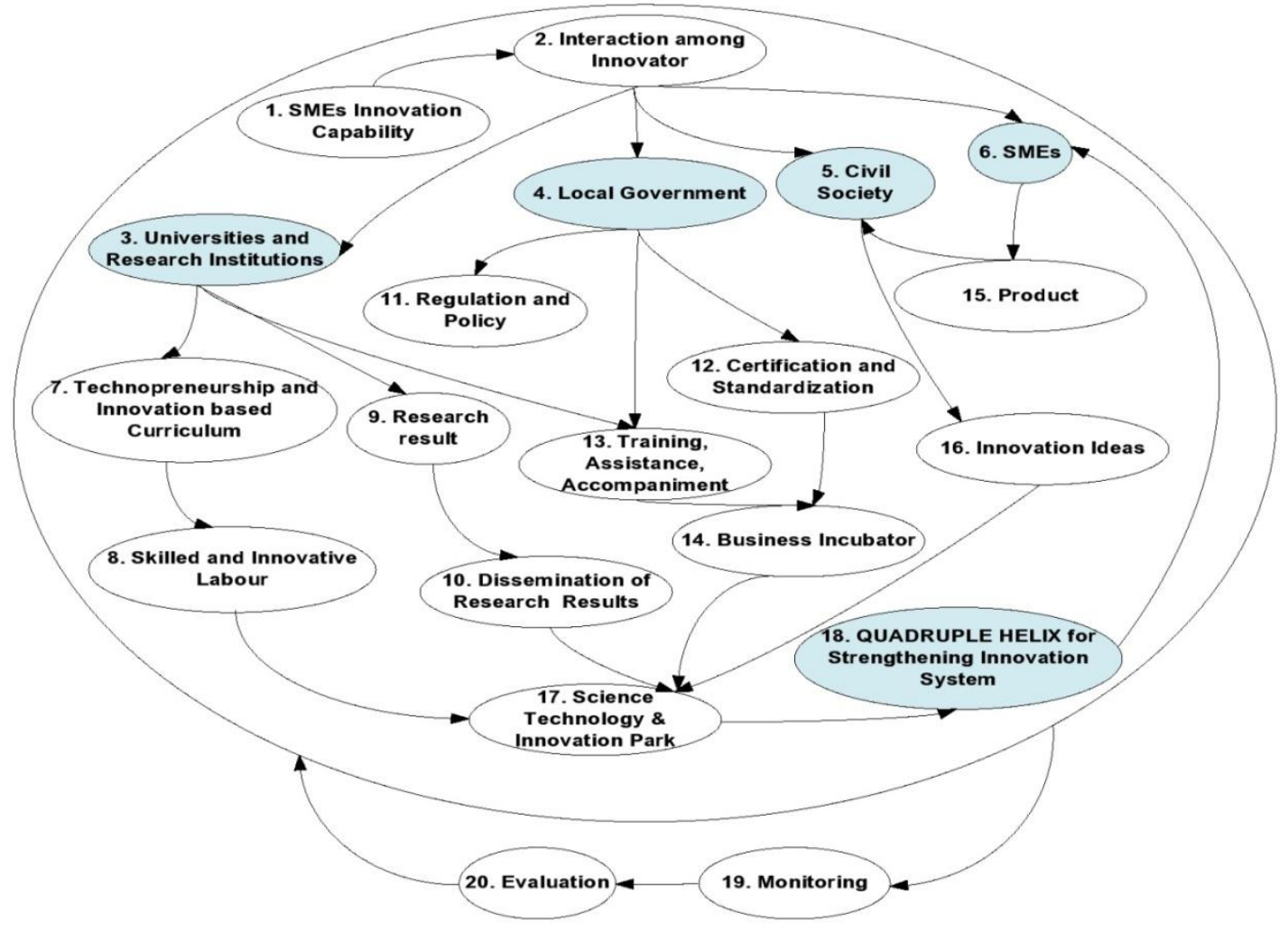

Figure 4.Conceptual Model of SME Innovation Capability Improvement

Business incubation process has the advantages of (1) intensive and continuous mentoring within 2-3 years, (2) mentoring people to solve problems, (3) mentoring is equipped with supporting services and facilities $7 \mathrm{~S}$ (space / space; shared / shared facilities such as pilot plant, equipment and laboratory; service / various consultations; support / support and access; development skills / technical guidance; seed capital / funding; and synergy / synergy), (4) high success above $50 \%$ compared to without incubation (under $10 \%$ ), and (5) development of the marketing area.

Dewi (2012) explains that there is no synergism between research institutions (universities) and business incubators, as well as the number of business incubators that have stagnated. University research is also often not marketable or not "selling power", even research orientation tends to be inconsistent with market needs. The results of research or university innovations that have the potential for commercialization are still very rare that are patented or registered to get the protection of intellectual property rights. In fact, the results of inventions or innovations at universities should be in line with the market or even be able to provide benefits directly to the community.

\section{Standardization and Certification of Fishery Products}

Fishery products are one type of food that needs attention to food security. Fishery products can be an intermediary medium for pathogenic and parasitic bacteria that can infect and cause disease in humans. Like the results of Rahmawaty et al. research (2014) that during 2010-2012 there was a rejection of Indonesian products dominated by fishery products, with the main causes being Salmonella and filthy. The cause of the rejection is related to GMP (Good Manufacturing Practices), sanitation and the application of HACCP (Hazard Analysis \& Critical Control Point). Thus fishery products need to be handled properly from upstream to downstream through the implementation of good practices on each line to ensure quality and safety.

According to the results of research by Hasbullah et al. (2015), the preparation and implementation of production SOPs, ownership of PIRT (Pangan Industri Rumah Tangga) certificates, and halal, good packaging usage and attractive designs can improve product quality and competitiveness. For this reason, small and medium business actors need to receive education and assistance in implementing food safety standards so as to produce safe and quality products.

\section{Dissemination of University Research Results}

The existence of a paradigm shift from the resource-based view to knowledge management requires companies to further improve the management and use of all knowledge possessed by the company and its employees. Knowledge management is regarded as the best strategy used by 
businesses to increase business competition because knowledge is a strategic resource that enables business people to gain a higher level of competitiveness and innovation (Chirico, 2008). Through good knowledge management, and effective knowledge sharing activities, the learning process in the organization can be accelerated and can improve the performance of the organization.

In research activities, dissemination can be seen as a process of communicating research technology using several methods of counseling through the media and broader with the aim of changing target behavior. Changes expected from dissemination activities will occur in the cognitive aspects (knowledge - P), affective (attitude - S) and psychomotor (skills - K). These changes go in the direction that is in accordance with the concept and the right or the right way.

\section{Recommend The Establishment of Science Park/Technopark Based Fish Processing \\ Technopark was an integrated area that} develops technology and innovation for research, combining industry, universities, and research centers, funded by the national and local government, in a single location that allows for the flow of information and technology more efficiently. Technopark or Sciencepark was an integrated area that allows the flow of information and technology more efficiently and quickly. The results of research to become an innovation and technology that benefit the society, might be able to be a downstream product and commercialized to the industry, because innovation becomes the nation's demands in promoting independent economic growth. The goal of technopark was to create a permanent link between high academics, industry/business/finance, government, and society.

\section{Compare the Model With the Real World}

Comparison of the conceptual model with the real word is show at Table 3 .

Table 3. Comparison of the conceptual model to the real world

\begin{tabular}{llll}
\hline \multicolumn{1}{c}{ Conceptual Model } & \multicolumn{2}{c}{ Real World } & \multicolumn{2}{c}{$\begin{array}{c}\text { Reflection using theoretical framework \& } \\
\text { problem solving }\end{array}$} \\
\hline $\begin{array}{l}\text { Technopreneurship- } \\
\text { based curriculum and } \\
\text { technology innovation }\end{array}$ & $\begin{array}{l}\text { There was still a lack of Improvement might be initiated from the } \\
\text { technopreneurship and innovation } \\
\text { substance in the curriculum thus } \\
\text { causing the lack of ability from } \\
\text { graduates to do job creation in the }\end{array}$ & $\begin{array}{l}\text { technopreneurship based curriculum and } \\
\text { technological innovation. }\end{array}$
\end{tabular}
field of agro-industry.

\begin{tabular}{ll}
\hline Standardization and & SMEs had limited knowledge \\
Certification of Product & about standardization and \\
& certification of products and the \\
& cost of standardization and \\
& certification were relatively \\
& expensive
\end{tabular}

Standardization and product certification served as a guarantee for the quality of a product, and increase the probability of the company to export.

\begin{tabular}{ll}
\hline Business Incubation & There was no business incubation \\
program which is a collaboration \\
of all innovation actors, which \\
already existed the colleges that \\
acted as business incubators.
\end{tabular}

The business incubation program which was the collaboration of all innovation actors such as SMEs, local government, universities and research institutes, and society, was expected to develop technopreneur-based entrepreneurship spirit of college graduates, the young generation, and other new developing businessmen of new business.

\begin{tabular}{lll}
\hline $\begin{array}{l}\text { Dissemination of } \\
\text { university research } \\
\text { results }\end{array}$ & $\begin{array}{l}\text { Disseminated research results are } \\
\text { limited to fellow academics }\end{array}$ & $\begin{array}{l}\text { Dissemination of research results in addition } \\
\text { to academics must also involve local } \\
\text { governments, SMEs, and the community as } \\
\text { end users of the product. }\end{array}$ \\
\hline $\begin{array}{l}\text { Science } \\
\begin{array}{l}\text { Park/Technopark based } \\
\text { fish processing }\end{array}\end{array}$ & $\begin{array}{l}\text { There was no Science Park/ } \\
\text { Technopark based on fish } \\
\text { processing }\end{array}$ & $\begin{array}{l}\text { Technopark could be a permanent link } \\
\text { between universities, local governments, } \\
\text { SMEs, and communities, thus making SMEs } \\
\text { stronger in the face of competitors. }\end{array}$
\end{tabular}




\section{Set The Feasible and Required Changes}

From the above explanation, the policy recommendation to improve the competitiveness of milkfish SMEs in the Banten Province was to improve the innovation capabilities of SMEs, one of which could be achieved through the enhancing of cooperation and interaction between innovation actors. With innovations made by four innovation actors, namely SMEs, local governments, universities, and educational institutions, as well as the community, or Quadruple Helix Innovation, the objectives were expected to be more easily realized.

By Quadruple Helix Innovation, the fishery products processing small and medium enterprises (SME) would be more competitive, as they produce standardized and certified products, had skilled and innovative Human Resources, had access to financial and marketing resources and research results from universities and research institutes. This is in accordance with the opinion of Anton et al. (2015), which stated that the SMEs competitiveness sourced from the level of innovation, entrepreneurship, human capital, financial resources, market potential, and business strategy. SMEs also required government assistance to develop the marketing networks and access to financial institutions.

\section{Take an Action To Fix The Situation}

The strategy to improve the competitiveness of milkfish satay SMEs in Banten Province was conducted through the improvement of SME innovation capability. The capability of SME innovation in this research was achieved through the increasement of cooperation and interaction between innovation actors, i.e SMEs, local government, universities, and educational institutions, as well as the community or also called Quadruple Helix Model.

The Quadruple Helix Model was an ideal model for describing innovation systems that require a more active role in society. The model explained that society was not only an intermediary between government, academia and business people but also as a creator of ideas, innovation, knowledge or technology based on their experiences, needs, cultures or local wisdom. In the Quadruple Helix Model, the innovations and technologies resulting from an innovation system were more communityoriented or user. The result of Mulyana and Sutapa (2014), creativity and innovation could be increased through the quadruple helix simultaneously. Similarly, the competitive advantage and performance could be enhanced when creativity and innovation were conducted in accordance with the needs of the consumer.

To improve the capability of small and medium business enterprises innovation, various work programs could be jointly conducted, i.e (1) technopreneurship-based curriculum and technological innovation, (2 business incubation program (3) standardization and certification of fishery products, (4) dissemination of university research results and (5) Science Park/ Technopark based on fish processing.

\section{CONCLUSIONS AND RECOMMENDATIONS}

The results showed that the low innovation capability of small-scale fish processing businesses in Banten Province was caused by the low level of cooperation and interaction among innovators. The improvement of the innovation capability of SME fish processing can be done through strengthening innovation collaboration among four innovation actors, namely SMEs, local governments, universities and other research institutions, and the community, also called Quadruple Helix Innovation, through programs (1) Technopreneurship and innovation based curriculum (2) business incubation (3) standardization and certification of fishery products, (4) dissemination of research results, and (5) processing-based Science Park / Technopark. The recommendations given from the results of this study are that the innovation system is not only seen from a short-term perspective, but also from a midterm, as well as long-term perspective, namely in the form of a policy strategy.

\section{REFERENCES}

Agustina TS. 2011. Peran inkubator bisnis perguruan tinggi dalam meminimalkan resiko kegagalan bagi wirausaha baru pada tahap awal (Start Up). Majalah Ekonomi. 21(1).

Anggraeni SK, Maarif MS, Sukardi, Raharja S. 2018. Penentuan produk unggulan usaha kecil menengah pengolahan ikan di kota serang. Prosiding Seminar Nasional Teknik Industri Universitas Gajah Mada 2018. Jogjakarta. 17 Oktober 2018.

Anton SA, Muzakan I, Muhammad WF, Syamsudin, Sidiq NP. 2015. An Assessment of SME Competitiveness in Indonesia. Journal of Competitiveness. 7(2): 60-74.

Checkland P. 1981. Systems Thinking, Systems Practice. Chichester : Wiley \& Sons.

Checkland P dan Scholes J. 1990. Soft Sistem Methodology in Action. England : Jhon Wiley \& Sons Ltd.

Chirico F. 2008. Knowledge accumulation in family firms: evidence from four case studies. International Small Business Journal. 26 (4):433-462.

Delbridge R. 2008. An illustrative application of soft systems methodology (SSM) in a library and information service context: process and outcome. Library Management. 29(6): 538-555. 
Dewi YA. 2012. Inovasi spesifik lokasi untuk inkubator teknologi mendukung pengembangan ekonomi lokal. Jurnal Analisis Kebijakan Pertanian. 10(4): 299312.

Eriyatno dan Larasati. 2013. Ilmu Sistem Jilid 2: Meningkatkan Integrasi dan Koordinasi Manajemen. Surabaya : Penerbit Guna Widya.

Fadhil R, Qanytah, Hastati DY, Maarif M. 2018. Development strategy for a quality management system of gayo coffee agroindustry using soft systems methodology. Periodica Polytechnica Social and Management Sciences. 26(2):168-178.

Haryati S, Munandar H. 2012. Application of zero waste concept on milkfish shredded meat processing. Jurnal Perikanan dan Kelautan Untirta. 2(2): 127-130.

Hasbullah R, Surahman M, Yani A, Almada DP, Elisa NF. 2014. Model pendampingan UMKM pangan melalui Inkubator Bisnis Perguruan Tinggi. Jurnal Ilmu Pertanian Indonesia. 19(1): 43-49.

Hasibuan S. 2015. SMEs Development Strategy for Competitive and Sustainable Typical Local Snack of Banten Province. International Journal on Advanced Science Engineering Information Technology. 5 (6) : 410-414.

Ibrahim MA, Malek A, dan Salman A. 2015. Evaluating the development of technopreneurs: A case study of PPR Telecenter Jalan Jelatik. Journal of Social Sciences and Humanities. 2: 157-161.

Jusoh S. 2006. incubators as catalysts in developing high technology businesses: malaysia's experience. ATDF Journal. 3(1):25-29.

Kosasih W, Ahmad, Lithrone LS, Utama DW. 2016. Peranan pendidikan technopreneurship untuk pembangunan berkelanjutan : Studi Konseptual. Jurnal Rekayasa Sistem Industri. 5(2) : 79-88.

Liu WB, Meng W, Mingers J, Tang N, Wang W. 2012. Developing a performance management system using soft systems methodology: A Chinese case study. European Journal Operational Research. 223(2): 529-540.

Lumpkin GT dan Dess GG. 2001. Linking two dimensions of entrepreneurial orientation to firm performance: The moderating role of environment and industry life cycle. Journal Business Venturing. 16: 429-451

Lundvall B. 1992. National Innovation Sistems: Towards a Theory of Innovation and Interactive Learning. London : Pinter Publishers.

Metcalfe S. 1995. The Economic Foundations of Technology Policy: Equilibrium and Evolutionary Perspectives, in Stoneman, P. (ed.), Handbook of the Economics of Innovation and Technological Change. Oxford.

Mulyana S. 2014. Peningkatan kapabiltas inovasi, keunggulan bersaing dan kinerja melalui pendekatan quadruple helix: studi pada industri kreatif sektor fashion. Jurnal Manajemen Teknologi. 13 (3): 304-321.

Nagi EWT, To CKM, Ching VSM, Chan LK, Lee MCM, Choi YS, Chai PYF. 2012. Development of the conceptual model of energy and utility management in textile processing: a soft systems approach. International Journal Production Economics. 135(2): 607-617.

Nelson R. 1993. National Innovation Sistems: A Comparative Analysis. New York (NY) : Oxford University Press.

Nur M. 2019. Pengaruh cara pengemasan, jenis bahan pengemas, dan lama penyimpanan terhadap sifat kimia, mikrobiologi, dan organoleptik sate bandeng (Chanos chanos). Jurnal Teknologi dan Industri Hasil Pertanian. 14(1): 1-11.

Nurhidayani PO. 2012. Strategi Pengembangan Usaha Sate Bandeng UKM Awal Putra Mandiri di Kota Serang, Banten. [skripsi]. Bogor (ID): Institut Pertanian Bogor.

Por J. 2008. The use of soft system methodology (SSM) in a serviced focused study on the personal tutor's role. Nurse Education in Practice. 8(1): 335-342.

Puspitasari FT. 2014. Analisis Profitabilitas Usaha dan Nilai Tambah Produk Sate Bandeng pada UKM Sate Bandeng di Kota Serang Banten [thesis]. Bogor (ID): Institut Pertanian Bogor.

Rahmawaty L, Rahayu W, dan Kusumaningrum H. 2014. Pengembangan strategi keamanan produk perikanan untuk ekspor ke amerika serikat. Jurnal Standarisasi. 16(2) :95-102.

Sadri S dan Sadri J. 2014. Using soft system methodology for understanding CSR international. Journal Multidisciplinary Approach and Studies. 1(4):110-123.

Sgourou E, Katsakiori P, Papaioannou I, Goutsos S, Adamides E. 2012. Using soft systems methodology as a systemic approach to safety performance evaluation. Procedia Engineering. 45 : 185-193.

Soetara A, Machfud, Affandi MJ, Maulana A. 2018. The design on conceptual model for continuation of lean manufacturing (LM) implementation in indonesia wood processing factory using soft system methodology. International Journal on Advanced Science Engineering Information Technology. 8(4):1302-1306.

Sonatha Y dan Prayama D. 2011. Penerapan soft sistem methodology dalam mengatasi 
permasalahan home monitoring. Jurnal Poli Rekayasa. 6 (2): 154-160.

Tajino A, James R, dan Kijima K. 2005. Beyond needs analysis: soft systems methodology for meaningful collaboration in EAP course design. Journal English for Academic Purposes. 4(1):27-42.

Wibowo, Hastuti I, dan Irawati Z. 2013. Kajian teknoekonomi sate bandeng iradiasi hasil produksi litbang BATAN. Teknoekonomi Jurnal Pendayagunaan Hasil Litbang Iptek Nuklir. 7(2) : 431-438.

Wilson B and Haperen KV. 2009. Improving regional policing: a review of protective services. Undertaking an audit of a method of analysis using soft systems methodology. International Journal Police Science and Management. 12 (2): 206-219.

Zarei B, Azizian S, Shishehgar M, Sadeghi S. 2014. Networking in marketing and advertising companies: a soft system methodology approach. International Technology Management Review. 4(1) : 42-57. 